\title{
A luta armada contra a Ditadura Militar: revisitando os debates sobre esse movimento no Brasil e na Argentina
}

\author{
The armed fight against Military Dictatorship: revisiting the discussions on this \\ movement in Brazil and Argentina
}

\author{
Luiz Fernando Mangea da Silva \\ Doutorando em História pela \\ Universidade Federal Rural do Rio de Janeiro \\ mangea.lfms@gmail.com
}

Resumo: O presente artigo tem como objetivo uma análise interpretativa da atuação das esquerdas revolucionárias que pegaram em armas contra a ditadura tanto no Brasil quanto na Argentina. Essa temática torna-se relevante para pensar como as esquerdas e as ditaduras latino-americanas utilizaram a violência como forma de levar seus projetos ideológicos e políticos, na segunda metade do século XX. Além disso, o presente trabalho procurou mostrar as semelhanças e as diferenças dos conflitos entre ambos os países. Devido à complexidade da temática, aqui tratada, esse artigo não tem nenhuma pretensão de esgotar toda a análise do tema exposto nessas laudas. $\mathrm{O}$ artigo está divido da seguinte forma: na introdução abordamos a ditadura civil-militar no Brasil e consequentemente a restrição da participação política; num segundo momento trataremos da luta armada no Brasil e o contexto político; em seguida a ditadura militar e a luta armada na Argentina e, por fim, as considerações finais.

Palavras-chave: ditadura militar, luta armada, violência.

\begin{abstract}
The article aims at an interpretive analysis of the actions of the revolutionary leftists who have taken up arms against the dictatorship in Brazil as well as in Argentina. This theme becomes relevant to think how the Latin American lefts and dictatorships used violence as a way to carry out their ideological and political projects in the second half of the twentieth century. In addition, the present work sought to show the similarities and the differences of the conflicts between both countries. Due to the complexity of the subject, here treated, this article has no pretension to exhaust all the analysis of the subject exposed in these pages. The article is divided as follows: in the introduction we address the civil-military dictatorship in Brazil and consequently the restriction of political participation; In a second moment we will deal with the armed struggle in Brazil and the political context; Then the military dictatorship and the armed struggle in Argentina and, finally, the final considerations.
\end{abstract}

Keywords: military dictatorship, armed struggle, violence. 


\section{Introdução}

A luta armada contra a ditadura militar ${ }^{1}$ instaurada no Brasil em 31 de março de 1964, só pode ser compreendida à medida que buscamos compreender também o próprio desenvolvimento político do regime que vigorou no país até 1985 e as estratégias de resistência da esquerda brasileira.

Os militares desde que assumiram o poder buscavam legitimar suas ações da seguinte forma: ora usavam do aparato repressivo, ora utilizavam um discurso que garantisse a aceitabilidade da ditadura, por meio de um "ideário" de que estariam incumbidos de preservar os valores que fundamentavam a democracia e a ordem social.

Quando estudamos os diversos setores da sociedade, tanto aqueles que apoiaram quanto aqueles que se colocaram em campos opostos ao da ditadura militar brasileira devemos nos interrogar sobre as bases sociais que ambos se assentavam.

As organizações sociais tanto política quanto econômica ou até religiosas que visam ao poder tendem a encontrar meios como forma de se legitimarem perante a sociedade. Esses meios que as organizações sociais utilizam para se sustentarem socialmente perante a sociedade podem ou não passar por vias democráticas.

Sendo assim, a pretensão pela busca da legitimidade do novo regime que passou a vigorar a partir de 1964 se deu por uma estratégia política na qual o regime militar lançava a tese de que estaria em defesa da democracia, da família e contrário à corrupção e ao comunismo.

Com essa busca da legitimidade como forma de desenvolver uma base social de apoio aos militares, principalmente, na fase inicial do seu regime ganharam a simpatia de uma parcela significativa da sociedade brasileira. Essa parcela da sociedade que simpatizava com a ditadura militar incluía setores como os meios de comunicação, o empresariado, tecnocratas e membros da hierarquia clerical.

Esses setores tentavam incutir a ideia de que os militares estavam defendendo os valores tradicionais da família, da democracia e combatendo a corrupção. Maria José de

\footnotetext{
${ }^{1}$ Segundo o historiador e professor de História Contemporânea da Universidade Federal Rural do Rio de Janeiro, Jean Rodrigues Sales, a expressão luta armada contra a ditadura militar é uma denominação consagrada no campo da História. A expressão trata-se também de um conjunto de ações que, embora tenha feito significativo uso de armas, nem sempre constituiu, necessariamente, um embate armado entre as esquerdas e os militares como sugere a própria terminologia. (SALES, 2015: 87-109) Cabe ressaltar que o autor não utiliza o termo ditadura civil-militar, em raras exceções, o emprega apenas para se referir à ditadura militar, preferindo a expressão golpe civil-militar. No entanto, eu utilizo como designação do movimento político que depôs o presidente da República, João Goulart, em março de 1964,ditadura civilmilitar. Isso por ter havido adesão de grupos e indivíduos não fardados no golpe.
} 
Rezende ressalta que: "A formulação de um ideário de democracia pelos militares, tecnoburocratas e representantes do grande capital objetivava funcionar como um tipo de esteira para amenização dos conflitos sociais" (REZENDE, 2001: 87).

No entanto, não demorou muito para que o novo regime começasse a mostrar sua face autoritária. Para por esse autoritarismo em prática, os militares recorreram aos chamados Atos Institucionais (AI). Desse modo, o Ato Institucional n. ${ }^{\circ} 1$ (AI-1) foi baixado por uma junta militar composta pelos comandantes do Exército, da Marinha e da Aeronáutica em 09 de abril de 1964. O AI-1 manteve a Constituição de 1945, mas com modificações, principalmente, em relação ao funcionamento do Congresso Nacional. O objetivo desse ato foi fortalecer o poder do Executivo e reduzir o campo de atuação do Congresso.

Com esse Ato Institucional, o Congresso continuava funcionando, porém, com limitações no campo político. ${ }^{2}$ Além disso, as imunidades parlamentares foram suspensas, autorizando o "Comando Supremo da Revolução"3 a cassar mandatos dos parlamentares e a suspender por até dez anos os seus direitos políticos. Com esse ato criou-se socialmente uma base legítima para a instauração dos chamados Inquéritos Policial-Militares (IPMs $)^{4}$, instrumentos utilizados corriqueiramente para interrogar os opositores do novo regime.

A partir desse momento, a ditadura militar passou a desencadear legalmente perseguições a todos aqueles que pensavam e agiam politicamente diferente do regime. Ocorrendo assim, as primeiras prisões e torturas das pessoas que faziam parte do núcleo da esquerda brasileira.

No entanto, havia a possibilidade de se utilizar o instituto do habeas corpus como garantia da liberdade contra o autoritarismo praticado pelo Estado. Apesar de já haver uma repressão explicita por parte dos militares, ainda havia uma margem para a resistência à medida que os opositores do regime podiam recorrer aos tribunais e à

\footnotetext{
${ }^{2}$ Esse Ato Institucional já mostrava o autoritarismo por parte dos militares que tomaram o poder em março de 1964. Isso porque concentrava o poder nas mãos do presidente da República, uma vez ele ficava autorizado a enviar ao Congresso projetos de lei que deveriam ser apreciados no prazo de trinta dias na Câmara e em igual prazo no Senado; caso contrário, seriam considerados aprovados. Ora, isso já mostrava de certa forma que apesar do apoio de setores da sociedade civil ao golpe, mas o comando das ações políticas ficava com os militares (FAUSTO, 2012: 257-258).

3 Termo utilizado tanto por Boris Fausto quanto Carlos Fico para designar o comando dos militares que passaram conduzir o poder político no país (FAUSTO, 2012: 258; FICO, 2001: 36).

4 Para Carlos Fico, o Inquérito Policial Militar (IPM) tinha como objetivo apurar crimes militares praticados contra o Estado e a ordem política e social. Isso criou as condições necessárias para que vários coronéis, tenentes-coronéis, majores, e capitães mais exaltados persistissem na "caça às bruxas", mesmo depois da posse do General Humberto de Alencar Castelo Branco, uma vez que eles passaram a assumir a responsabilidades pela condução desses IPMs (FICO, 2001: 36).
} 
imprensa alternativa que ainda era relativamente livre. Tanto foi assim que o jornal carioca Correio da Manhã já denunciava publicamente as prisões de pessoas ligadas às organizações de esquerda e as práticas arbitrárias de interrogação com imposição de torturas.

Diante das perseguições políticas desencadeadas logo após o AI-1 era difícil acreditar na propaganda difundida pela Escola Superior de Guerra (ESG) de que a ditadura militar exercia a função de defender a democracia, os valores tradicionais da família e o combate a corrupção.

Apesar da cassação dos direitos políticos daqueles que se opunham ao regime ter sido uma forma de controle por parte dos militares em relação à oposição, as eleições de outubro de 1965, mostraram que ela (a oposição) cresceu em Estados importantes como o do Rio de Janeiro e o de Minas Gerais.

Explicando como o resultado dessas eleições chamou a atenção dos militares, Boris Fausto diz o seguinte: "O resultado das urnas alarmou os meios militares. Os grupos de linha dura, adversários dos castelistas, viram nele a prova de que o governo era muito complacente com seus inimigos" (FAUSTO, 2012: 262).

Sob a pressão desses grupos chamados de "linha dura" o general Castelo Branco baixou, em outubro de 1965, o Ato Institucional n. 2 (AI-2). Esse Ato Institucional concentrou ainda mais poderes nas mãos do presidente da República à medida que estabeleceu que o presidente poderia baixar decretos-leis em matérias de interesse da segurança nacional, além da extinção do multipartidarismo. Criando assim, o bipartidarismo: a Aliança Renovadora Nacional (Arena) e o Movimento Democrático Brasileiro (MDB).

Nas eleições de 1966, o grupo castelista não conseguiu fazer seu sucessor. Em 03 de outubro de 1966, o general Artur da Costa e Silva foi eleito pelo Congresso presidente da República e para vice-presidente um civil, Pedro Aleixo. O general tomou posse no dia 15 de março de 1967. A eleição de Costa e Silva significava uma vitória da chamada "linha dura" e dos nacionalistas autoritários das Forças Armadas descontentes com a política desenvolvida por Castelo Branco.

O projeto político autoritário que começou a ganhar forças em 1964 teve seu auge em 13 de dezembro de 1968, com a publicação do Ato Institucional n. 5 (AI-5). Após esse Ato Institucional, os movimentos contrários à ditadura militar foram considerados ilegais pelo governo militar, passando a atuar na clandestinidade. De acordo com Marcelo Ridenti, “vários operários foram suspensos, demitidos, 
perseguidos, aberta ou veladamente, enquanto os mais engajados viram-se obrigados a entrar para a clandestinidade, a fim de não serem presos" (RIDENTI, 1993: 186).

A partir desse momento, prevalecia no Brasil o arbítrio e a institucionalização da repressão e da tortura por parte do Estado, criando na sociedade brasileira uma cultura do medo ${ }^{5}$, que restringia a participação em atividades religiosa, sindical e política.

Com o aumento da repressão e da institucionalização da tortura, setores da sociedade civil, como movimentos grevistas, estudantis e setores mais progressistas da Igreja Católica, que em certa medida contavam com o apoio da elite eclesiástica, passaram a ser opor ao regime vigente.

Podemos destacar, por exemplo, a atuação do arcebispo de Olinda e Recife, D. Hélder Pessoa Câmara, a mobilização dos estudantes em torno da União Nacional dos Estudantes (UNE), as mobilizações de 1968, como o protesto pela morte do estudante secundarista Edson Luís Lima Souto, morto em março de 1968, pela política militar do Rio de Janeiro e a passeata dos cem mil que ocorreu em junho desse mesmo ano também no Rio de Janeiro.

Essa passeata protestava contra a violência policial que culminou com a morte do estudante e da restrição a qualquer manifestação política que se colocasse contrária à ditadura militar. Esse movimento contava com a participação de estudantes, intelectuais, operários, profissionais liberais e religiosos, além da adesão das pessoas contrárias às práticas autoritárias da ditadura. Todo esse cenário de restrição da participação política e o aumento da repressão por parte dos militares contribuiu para que movimentos de esquerda pegassem em armas contra a ditadura.

\section{A luta armada no Brasil: uma breve releitura desse episódio político da história recente}

Quando abordamos a luta armada no Brasil devemos nos interrogar sobre as diversas interpretações direcionadas para as ações políticas e culturais da esquerda brasileira. Em outras palavras, devemos levar com consideração a heterogeneidade da esquerda que pegou em armas contra a ditadura militar.

\footnotetext{
${ }^{5}$ A cultura do medo tinha três importantes componentes psicológicos: o primeiro era o silêncio imposto à sociedade pela rigorosa censura. $\mathrm{O}$ segundo foi o isolamento naqueles indivíduos que sofriam diretamente com a repressão. Por fim um sentimento de total desesperança passou a prevalecer naqueles indivíduos que eram contrários a ditadura militar. O silêncio, o isolamento e a descrença faziam parte dos elementos da cultura do medo (ALVES, 1984: 205-206).
} 
Existem três obras que podem ser consideradas como clássicas para pensar como se deu o desenvolvimento das esquerdas armadas no Brasil durante as décadas de 1960 e 1970. A obra de Jacob Gorender, Combate nas Trevas (1987); ${ }^{6}$ a de Daniel Aarão Reis Filho, A revolução faltou ao encontro: os comunistas no Brasil (1990) ${ }^{7}$ e a de Marcelo Ridenti, O fantasma da revolução brasileira (1993) ${ }^{8}$.

O historiador, Jean Rodrigues Sales, em um artigo publicado pela revista Taller, intitulado Guerrilha e revolução: um balanço dos estudos e debates sobre a luta armada contra a ditadura militar no Brasil (2015), faz um balanço historiográfico sobre diversos trabalhos que trataram da temática da luta armada no Brasil.

Desse modo, o autor recorreu a livros de memória, biografias (livros produzidos por acadêmicos, dissertações e teses), entrevistas e outros trabalhos produzidos por exmilitantes. O artigo produzido por Sales se torna relevante tanto para pensar como se deu o desenvolvimento da produção historiográfica sobre a temática acerca da luta armada brasileira, seja ela dentro da academia ou por militantes e ex-militantes; quanto pela busca de se compreender como ocorreram as ações políticas desempenhadas pela esquerda armada contra a ditadura militar.

Portanto, as primeiras reflexões sobre a luta armada no Brasil se deram ainda no decorrer do próprio regime militar. Assim Sales afirma que: “As primeiras produções a respeito da luta armada contra a ditadura militar se iniciaram nos anos 1970 e tiveram como autores os próprios militantes e ex-militantes da esquerda revolucionária" (SALES, 2015: 87-109).

A partir de 1979, surgem diversos trabalhos de biografias e de autobiografias de militantes da esquerda armada. De acordo com Denise Rollemberg, os militantes foram vencidos pelo poder das armas dos militares, mas continuaram guerreando pela preservação da memória.

A autora, em um trabalho intitulado, Esquecimento das memórias, tenta responder o seguinte questionamento: "Por que tantas biografias e autobiografias de exmilitantes da luta armada?" Denise Rollemberg responde essa pergunta da seguinte forma: "Da parte dos que viveram a luta armada, a necessidade de contar a história, a

\footnotetext{
${ }^{6}$ Nessa obra, Gorender faz uma análise minuciosa sobre a atuação da esquerda brasileira que pegou em armas contra os governos ditatórias que tomaram o poder a partir de 1964.

${ }^{7} \mathrm{O}$ professor de História Contemporânea da Universidade Federal Fluminense faz uma análise das organizações de esquerda na década de 1960 e suas atuações no campo da política, além da dinâmica interna dessas organizações comunistas.

${ }^{8}$ Nessa obra, Ridenti faz um balanço sociológico da trágica e heróica experiência da luta armada contra a ditadura.
} 
sua história. Muitos associam falar, narrar à resistência, a dar sentido aos que não sobreviveram, à sobrevivência individual ou social de uma geração ou de uma época" (ROLLEMBERG, 2006: 81-91).

As relações sociais em que os indivíduos estabelecem com o seu passado são relações dinâmicas e às vezes contraditórias. À medida que os ex-militantes da luta armada sentem a necessidade de lembrar e contar o passado, esses indivíduos elaboram e reelaboram significados para dar sentido não só ao passado vivido, mas também ao presente.

Essa reinterpretação tanto do passado quanto do presente pelos ex-militantes da luta armada encontra-se dentro dos limites epistemológicos da memória ${ }^{9}$ e da História. Por vezes a História foi considerada por romancistas, filósofos e por cientistas sociais indigna de estima justamente por causa de seu vínculo com a memória.

Sabina Loriga explica como os historiadores lidaram com essa crítica: "Vários deles pensaram que, para ter acesso ao nível do conceito e da verdadeira ciência, era preciso submeter a memória, dissolver sua energia incontrolável no campo da história, ou que era hora de acabar com ela de uma vez por todas, eliminando todo tipo de vínculos" (LORIGA, 2009: 15).

Quando analisamos o debate em torno da construção da memória vemos que esse debate seguiu muitas trilhas, por vezes obedecendo às margens que o tempo lhe ofereceu ou rompendo com os limites da História Política de outrora, e ocupando vastos territórios. A memória e a História fazem parte da ação humana determinando certas práticas, acontecimentos e consolidam símbolos e significados que transcendem determinadas fronteiras, limites e espaços.

A memória é um conjunto de signos e imagens vivenciados pelos indivíduos no passado. Os signos e as imagens são emitidos a partir do presente para se construir uma narrativa sobre o passado. O problema é quando passado e presente emitem signos e imagens distintos. Para o historiador medievalista Jacques Le Goff:

A distinção entre passado e presente é um elemento essencial da concepção do tempo. É, pois, uma operação fundamental da consciência e da ciência históricas. Como o presente não se pode limitar a um instante, a um ponto, a

\footnotetext{
${ }^{9}$ Para Jacques Le Goff, empreender o conceito de memória é primordial. Isso porque a memória tal como ela surge nas ciências sociais fundamentalmente na História e na Antropologia se ocupa mais da memória coletiva do que da memória individual. Le Goff ressalta que é importante descrever sumariamente a nebulosa memória no campo científico global (LE GOFF, 2013: 387).
} 
definição da estrutura do presente, seja ou não consciente, é um problema primordial da operação histórica (LE GOFF, 2013: 193).

Quando abordamos a atuação política dos ex-militantes da luta armada é importante pensar a memória como um elemento que busca conservar certas informações, remetendo-nos em primeiro lugar a um conjunto de funções psíquicas, graças às quais os ex-militantes da esquerda brasileira e argentina podem atualizar impressões ou informações passadas, ou que eles representam como passadas.

Pois ao mesmo tempo em que esses ex-militantes ressaltam a atuação política tanto nos aspectos individuais quanto nos aspectos coletivos contra a ditadura civilmilitar, também deixam transparecer em forma de narrativa que viveram num período da história no qual não se apresentava um futuro ou um presente, mas somente a barbárie de um tempo passado.

Todavia, essas relações psíquicas entre passado, presente e memória variam conforme os grupos sociais, culturais e políticos envolvidos no processo histórico. No imaginário tanto individual quanto coletivo podem estabelecer novos sentidos para as ações do passado, para a identidade e para os espaços sociais que atuam no cenário do jogo político do presente. Desse modo, a memória torna-se um fenômeno psicológico que liga à vida social dos indivíduos em sociedade. A presença ou a ausência de uma determinada memória depende do ambiente social do presente.

Pois, trata-se da aquisição de uma retórica de passado que se fundamenta por meio de textos, de imagens e da oralidade. Os indivíduos organizados em sociedade tendem propositalmente a lembrar ou esquecer determinados fenômenos da memória social. Le Goff ressalta que: "Os fenômenos da memória, tanto nos seus aspectos biológicos como nos psicológicos, mais não são do que os resultados de sistemas dinâmicos de organização e apenas existem na medida em que a organização os mantém ou reconstitui" (LE GOFF, 2013: 388).

Assim, quando relacionamos em nossas pesquisas o debate sobre memória e história. Percebemos que não se tratam de simples variáveis, bem delimitadas por um conjunto de valores específicos definidos socialmente. Mas se trata de uma epistemologia histórica construída socialmente em que a memória se enquadra dentro uma construção cultural dos indivíduos que viveram o passado histórico, ao passo que a história como uma "ciência do passado" enquadra dentro das operações intelectuais que atendem as formas e os critérios da comunidade científica constituída de historiadores. 
O historiador Marcos Napolitano ressalta que: "História e memória se confundem e entram em choque ao falar sobre um mesmo passado, sobretudo quando há processos políticos que ainda estão em jogo e quando muitos dos protagonistas de ontem ainda estão vivos e atuantes" (NAPOLITANO, 2015: 09-44).

Sabemos que a memória tem seu caráter seletivo. Ela pode ocultar evidências relevantes, uma vez que o indivíduo pode arbitrariamente alterar e modificar os acontecimentos e os fatos que foram constituídos pelo passado histórico. Com isso, não estamos negando o valor testemunhal dos indivíduos que viveram um determinado acontecimento histórico. Também não estamos afirmando que exista uma memória autêntica ou uma memória mentirosa, isto é, falsificadora da realidade social.

O que estamos chamando a atenção é para as batalhas que se dão em torno da disputa pela memória. Quando se trata da luta armada no Brasil contra a ditadura militar isso fica evidente. Nesse sentido, Daniel Aarão Reis explica que: "Nas batalhas de memória, o jogo nunca está definitivamente disputado, as areias são sempre movediças e os pontos considerados ganhos podem ser subitamente perdidos" (REIS, 2004: 29-52).

Quanto aos motivos que levaram a esquerda a empunhar armas contra a ditadura militar não há um consenso entre os historiadores. As interpretações são diversas e difusas. A meu ver, não houve uma motivação específica que levaram diversos grupos a pegarem em armas contra os militares. As motivações estão inseridas dentro de um contexto social e política da época.

Sendo assim, não podemos deixar de mencionar que estávamos vivendo sob o contexto social e político da Guerra Fria. De um lado, a busca hegemônica do capitalismo por meio da expansão imperialista dos Estados Unidos da América, do outro, o avanço do socialismo nos países do leste europeu influenciados pela União das Repúblicas Socialistas Soviéticas. Além das lutas de libertação nacional tanto Oriente quanto o Ocidente.

Pois, simbolicamente, havia uma influência não só da Revolução Russa, mas também de outros acontecimentos que indicavam uma alternativa para a superação do capitalismo como a Revolução Chinesa (1949), mais precisamente, a Revolução Cubana (1959), essa última com forte influência nos países chamados de Terceiro Mundo. ${ }^{10}$

\footnotetext{
${ }^{10}$ Para Marcelo Ridenti, o termo Terceiro Mundo foi cunhado na época para designar as nações fora do eixo diretamente vinculado ou à órbita de interesses do mundo dito "ocidental", capitaneado pelos Estados Unidos da América, ou à órbita dos países socialistas de um mundo sob hegemonia da União Soviética (RIDENTI, 2007: 21-51).
} 
O simbolismo da Revolução Cubana impactou diversos movimentos da esquerda brasileira desde movimentos operários, camponeses, militares subalternos, setores significativos dos meios estudantis, artísticos, intelectuais da esquerda partidária e católica. Pensar a luta armada contra a ditadura militar é ao mesmo tempo trazer para o campo histográfico um tema central para compreender a história política recente do Brasil, mas também compreender os limites do próprio desenvolvimento da democracia no Continente Latino Americano.

As ditaduras militares que surgiram a partir da segunda metade do século $\mathrm{XX}$ ocuparam lugar de destaque na história recente dos países do Cone Sul da América Latina. Depois dessa explanação sobre atuação político-social da esquerda brasileira, que pegou em arma contra a ditadura militar, faremos uma análise de como se deu essa mesmo situação na Argentina.

\section{A ditadura militar e a luta armada na Argentina: a recordação de um episódio traumático}

A luta armada na Argentina se diferencia da luta armada no Brasil, pois existem especificidade tanto na estratégia ${ }^{11}$ quanto na tática ${ }^{12}$ contra a ditadura militar. Também as ações dos militares argentinos se diferenciaram das ações nos militares brasileiros, porque na Argentina essas práticas eram mais um processo de limpeza, isto é, funcionava como um processo de higienização dos movimentos que se opunham à ditadura militar argentina.

\footnotetext{
${ }^{11}$ Segundo Michel de Certeau, a estratégia é cálculo ou a manipulação das relações de forças que se torna possível a partir do momento em que um sujeito de querer e poder (uma empresa, um exército, uma cidade, uma instituição científica) pode ser isolada. Desse modo, a estratégia postula um lugar suscetível de ser circunscrito como algo próprio. Por isso, ela é a base para atingir um determinado fim ou alcançar um terminado objetivo. O funcionamento da estratégia é parecido com o trabalho desenvolvido pelos administradores de empresas que buscam operacionalizar toda racionalidade para gerir a relação com os clientes e afastar as ameaças dos inimigos que são as empresas concorrentes (CERTEAU, 2014: 93).

${ }^{12}$ De acordo com Michel de Certeau, a tática é uma ação calculada que é determinada pela ausência de um próprio. Então nenhuma delimitação de fora lhe fornece a condição de autonomia. Sendo assim, a tática não tem por lugar senão o do outro. E por isso deve jogar com o terreno que lhe é imposto tal como o organiza a lei de uma força estranha. Para Certeau, a tática é um movimento que se faz dentro do campo de visão do inimigo e no espaço controlado por ele controlado. Portanto, ele opera golpe por golpe, lance por lance. Para desenvolver a tática temos que ser vigilantes e atuar nas falhas que vão se abrindo no território de inimigo. Pois, a tática cria surpresas porque ela consegue estar onde ninguém espera. É onde desenvolve a astúcia. A tática é determinada pela ausência de pode, ao passo que a estratégia é organizada pelo postulado de um poder. Devido à ausência de poder, a tática é chamada por Certeau como a arte do fraco.(CERTEAU, 2014: 94-95).
} 
Aqueles que pegavam em armas contra a ditadura eram eliminados pela repressão quase imediatamente. Diferentemente, do modus operandi da ditadura brasileira que não eliminavam seus opositores de imediato, mas formulava Inquéritos Policiais Militares (IPMs), para apurar as ações ditas "subversivas", o que não significa afirmar que nesses interrogatórios não eram aplicados métodos torturas como forma de extrair confissões ou até mesmo culminando com a morte dos opositores à ditadura.

No entanto, não vamos aqui fazer um contraponto mostrando as semelhanças e as diferenças entre a luta armada da Argentina e a do Brasil, e suas relações políticas com as respectivas ditaduras. Nesse sentido, estamos penas sinalizando para o leitor que em cada país os movimentos de contestação dos golpes militares seguiram suas particularidades.

Em linhas gerais, podemos dividir a história política recente da Argentina e consequentemente a instauração de golpes militares e a atuação política da esquerda armada da seguinte forma. No período que vai de 1955 a 1963, pode ser considerado como o momento pela qual a história política argentina foi marcada pela censura da imprensa. Já o período de 1963 a 1976, temos uma fase marcada pela volta da democracia e pelo governo do médico Arturo Umberto Illia (1963-1966).

O presidente Arturo Umberto Illia, que exercia o cargo legalmente foi deposto no dia 28 de junho daquele ano e a partir de então se sucedeu uma série de governos de militares até 1973 e o fechamento político que vai culminar com o golpe do general Jorge Rafael Videla Redondo, em junho de 1976.

O período que vai de 1976 a 1983 pode ser considerado uma terceira fase desse processo político conturbado em que vivia a Argentina. Essa fase coincide com o discurso autoritário e com o aumento da repressão aos opositores do regime. Trata-se de um período no qual há um significativo aumento de pessoas sendo presas, torturadas e escamoteadas pela ditadura Argentina.

Assim como em outros países da América Latina que também passaram por golpes militares, havia uma ocultação por parte dos grandes meios de comunicação, dos episódios de torturas e desaparecimentos das vítimas da ditadura. Às vezes a imprensa colaborava com os militares difundindo falsas notícias dessas vítimas.

O quarto período teve início a partir do governo de Raúl Ricardo Alfonsín em 1983, esse foi um momento importante para a história política argentina, uma vez que foi marcado por uma paulatina abertura política. 
Outra situação que merece ser destacada é o silêncio da Igreja Católica na Argentina sobre as violações dos direitos humanos por parte da ditadura. De acordo com Julio Carreas, intelectual e ex-guerrilheiro argentino, a Igreja tinha conhecimento das existências de "campo de concentração" e de extermínio de jovens e adultos tanto de homens quanto de mulheres indefesos.

Diferentemente do posicionamento da Igreja Católica Brasileira, que também apoiou o golpe, mas não demorou em se colocar como uma alternativa de oposição a ditadura. Já na Argentina a Igreja só veio fazer autocrítica muitos anos depois.

Quando estudamos os grupos armados na Argentina, devemos observar a dinâmica do conflito e a formação social e política desses grupos. Sendo assim, podemos definir esses grupos genericamente como sendo setores da esquerda e setores da direita que lutavam para impor sua visão de mundo e conquistar o poder político, bem como o apoio da sociedade. Assim, os vários grupos de esquerda na argentina reivindicavam seu passado de luta contra a ditadura ou eram "acusados" por ela de serem grupos que atentavam contra a ordem estabelecida pelo Estado.

Em um primeiro momento, essa esquerda foi constituída basicamente por combatentes peronistas e pelos movimentos guerrilheiros, ao passo que a direita era composta pelos membros do Partido Militar e pelas Forças Armadas. Desse modo, a esquerda era formada por movimentos nacionalistas, trotskistas e peronistas da resistência à ditadura militar.

O Partido Militar congregava o exército, a Força Aérea, forças policiais e alguns partidos liberais menores como a Democracia Cristã e o partido político fundado pelo capitão Francisco Manrique. Os postos-chave da administração pública argentina vão ser ocupados por membros desse Partido.

A esquerda vai concentrar sua luta em duas frentes de batalha: pela libertação da dependência das classes dirigentes do país e pelo fim da dependência do imperialismo mundial capitalista. Para alcançar seus objetivos, a esquerda buscava uma aliança com os inimigos do Partido Militar e do imperialismo mundial capitalista representado pelos Estado Unidos da América.

Assim, a esquerda argentina buscou apoio de países comunistas como a China, a União das Repúblicas Socialistas Soviéticas e mais frequentemente de Cuba. Os objetivos da esquerda eram derrotar e aniquilar a "burguesia dependente da Argentina". A direita militar e seus aliados veem o comunismo como seu principal inimigo assim como em outros países latino-americanos contavam com apoio militar e econômico dos 
Estados Unidos. Pois, o Pentágono contribuiu com diversos golpes militares na América Latina. Samantha Viz Quadrat resume no complexo processo político vivido pala Argentina nesse período da seguinte forma:

A Argentina que enfrentou um período de forte instabilidade política desde a deposição de Juan Domingo Perón, em 1955, passando pela ditadura de Juan Carlos Onganía (1966-1970), até o golpe de 24 de março de 1976, que deu início à ditadura autodenominada Processo de Reorganização Nacional, que só terminou em 1983, com a eleição de Raul Alfonsín (QUADRAT, 2011: 240-273).

Tornou-se quase que um lugar comum pensar a atuação das ditaduras do Cone Sul a partir da Doutrina de Segurança Nacional criada Pentágono, já que os Estados Unidos eram vistos como sendo um país responsável pelos golpes militares que surgiram em vários países do Cone Sul. Conforme ressaltado anteriormente, os Estados Unidos da América especialmente durante o período da Guerra Fria demonstravam interesse político nessa região. Com o interesse dos Estados Unidos na região e na manutenção das ditaduras a Doutrina de Segurança Nacional passou a estar atrelada ao desenvolvimento econômico. A tese difundida pelo Pentágono era de que esses países só alcançariam prosperidade econômica pondo em prática a Doutrina de Segurança Nacional pensada e desenvolvida pelos americanos.

Essa doutrina desenvolveu no imaginário popular o discurso da existência do "inimigo interno" objetivando controlar e atingir as organizações de esquerdas que combatiam essas ditaduras. Seguindo essa mesma linha de raciocínio Quadrat explica que:

Para conter o avanço desse "inimigo" e se manter no poder, os militares procuraram exercer um excessivo controle na vida da sociedade civil, adaptando a doutrina à sua realidade. Isso acarretou um grande investimento no setor de inteligência, que, em alguns além da coleta e processamento da informação, ficou responsável por exercer a repressão (QUADRAT, 2011: 240-273).

Essa tese da defesa nacional para a Doutrina de Segurança Nacional estava presente no imaginário do exército argentino logo após a queda de Juan Domingo Perón 
em 1955. A partir desse momento histórico, a guerra se deu também nos aspectos ideológicos. Para a esquerda argentina tratava-se de uma guerra revolucionária contra o imperialismo Norte-Americano, ao passo que para a direita e para os militares tratava-se de uma guerra subversiva e contra o comunismo.

$\mathrm{Na}$ Argentina a violência política foi praticada de forma radical em ambos os lados. No entanto, o chamado "terror do Estado" vitimou os opositores quase por completo. O "terrorismo" praticado pelo Estado se deu com a atuação clandestina dos militares no seqüestro e desaparecimento daqueles que se opunham a ditadura argentina. A violência política praticada pelos militares impactou diretamente na política de defesa dos direitos humanos e na construção de uma memória de combate à ditadura na argentina.

Feita essa explanação geral, vamos analisar como a intelectualidade argentina interpretou esse conflito entre esquerda que empunharam armas e a ditadura militar? Como a ditadura perseguiu e combateu seus oponentes? Como a historiografia argentina analisou esse episódio traumático para a sociedade de um modo geral?

Para compreender o modo como a historiografia passou a abordar este tema é imprescindível situar o marco em que a narrativa sobre o golpe é construída pelos intelectuais argentinos. A evolução das diversas narrativas da memória social é construída com base nas representações do passado em um determinado espaço social.

As narrativas da memória social na Argentina, sobre a ditadura militar têm dado ênfase na defesa da justiça social e dos direito humanos. Para Hugo Vezzetti, nas origens dessa temática sobre a construção de uma memória social da violência cometida pelo Estado tem um caráter reativo e defensivo dessa memória.

Dessa forma, Vezzetti ressalta que: "La vigencia de los temas de la memoria, incluso lo que se puede llmar um deber de memoria, ha dependido de un acontecimento brutal, una situación limite para la sociedad y sus instituciones: el terrorismo y la criminalización del estado ocorridos en una escala nunca vista en el país" (VEZZETTI, 2016: 3).

À medida que Vezzetti defende a posição de que a memória tem um caráter reativo e defensivo ele nos chama atenção para o uso da memória como registro do passado. Para Vezzetti, a memória não é um registro espontâneo do passado. Sendo assim, a memória não pode ser considerada um marco de recuperação do passado, mas uma narrativa que dá sentido ao passado, partindo do presente e dentro de uma perspectiva de futuro. 
A memória é constituída por elementos ilusórios e seletivos com relação ao passado. Nesse sentido Jacques Le Goff ressalta que: "Os esquecimentos e os silêncios da história são reveladores desses mecanismos de manipulação da memória coletiva" (LE GOFF, 2013: 390).

Mas na Argentina essa memória da ditadura é pensada como um passado carregado de combate e tem por finalidade a busca por um Estado Democrático de Direito. A busca pela elaboração pública de uma memória sobre esse passado traumático da Argentina tem duas finalidades: fazer o uso do passado para enfrentar questões do tempo presente e condenar moralmente o uso da violência praticada tanto pelo Estado quando pela esquerda armada.

De acordo com a pesquisadora Marina Franco, as instâncias político-jurídicas das décadas de 1980 e 1990 estão enfrentando dois dilemas entre o esquecer e o recordar esse período histórico vivenciados pelos argentinos. Pois, há uma disputa pela memória decorrente dos defensores dos direitos humanos e dos diferentes grupos sociais. Inclusive, a partir de 1990 houve modificações nas leis argentinas com a finalidade de responsabilizar juridicamente os militares pela apropriação dos filhos dos prisioneiros políticos, além dos seqüestros e desaparecimentos daqueles que foram perseguidos pela ditadura militar argentina. Quadrat chama atenção para essa disputa da memória na Argentina da seguinte forma:

Em 15 de dezembro de 1983, Raul Alfonsín, primeiro presidente eleito pósditadura, criou a Comissão Nacional sobre o Desaparecimento de Pessoas (Conadep) com a missão de receber e investigar as denúncias sobre os crimes de violações de direitos humanos. Sob o comando do escritor Ernesto Sábato, a comissão recebeu cerca de 9 mil denúncias - número que gerou bastante polêmica, pois divergia, e muito do que foi apurado pelos grupos de defesa dos direitos humanos, que apontavam cerca de 30 mil mortos e desaparecidos (QUADRAT, 2011: 255-256).

Outros indivíduos, por sua vez, não querem ressuscitar essa memória porque entendem que os anos de luta armada foram um período representando por uma guerra suja, isto é, ambos os lados são responsáveis pelas consequências dos conflitos. Dito de outra forma significa afirmar que para uma parcela da população argentina, a sociedade era vítima da violência praticada tanto pelo Estado quanto pela esquerda armada. 
Isso porque os limites éticos do espaço social da política não abrem "brechas" para a violência, ou seja, a violência seria algo que deveria ficar fora do campo político. Essa ideia de que a sociedade foi vítima da violência tanto do "terrorismo" do Estado quanto da violência da esquerda armada devido à "guerra suja" é simbolizada pela metáfora da teoria dos dois demônios ${ }^{13}$.

Esse debate feito pela intelectualidade argentina se deu em torna da construção da memória durante o período no qual os argentinos chamam de Processo de Reoganización Nacional (CALVEIRO, 2013: 11), período no qual a repressão atuou de forma dura contra os opositores e no combate à luta armada.

Os anos de 1970 podem ser considerados como sendo o período em que os militares atuaram fortemente no combate à repressão. Foi um período em que houve vários desaparecimentos de pessoas que se opunham ao regime político argentino, ou seja, foi período considerado de maior repressão com diversos crimes cometidos pelas forças de seguranças. Diante dessa situação, a sociedade argentina fez um trabalho de valorização da memória coletiva, de tal envergadura, que toda a América Latina tomou conhecimento das atrocidades cometidas pelo regime militar.

Diferentemente do que ocorreu no Brasil com relação aos crimes cometidos pelo Estado no decorrer da ditadura civil-militar. Na Argentina houve um clamor social para identificar e responsabilizar os agentes públicos que praticaram o que alguns intelectuais chamam de "terrorismo de Estado" (CALVEIRO, 2013: 12).

À medida que há uma memória coletiva em torno da violência cometida pelo Estado não será possível sustentar a posição de que houve uma "guerra suja" simbolizada pela teoria dos dois demônios. Pois, uma vez que os militares devem ser identificados e responsabilizados pelos atentados que cometeram, a sociedade foi vitimada por um único demônio metaforizado por militares cruéis e ávidos por poder.

Com isso, surge outra explicação para o uso da violência praticada por grupo de esquerda. Essa explicação se fundamenta na lógica de que havendo um terrorismo de Estado, a sociedade não teria sido uma vítima imóvel. Ela (sociedade) teria potencializado também um terrorismo social como uma reação ao terrorismo praticado pelo Estado.

\footnotetext{
${ }^{13}$ A teoria dos dois demônios surgiu na Argentina a partir do início da década de 1990, por intelectuais que afirmavam que a sociedade foi acuada entre a violência praticada pelos dois grupos. De um lado, os militares, do outro, os militantes de esquerda. De acordo com essa teoria ambos deveriam ser responsabilizados pelos crimes que cometeram porque a violência extrapola o campo da política (FRANCO, 2005).
} 
Para Pilar Calveiro, o conflito envolvendo a ditadura e a esquerda armada na Argentina vai além da explicação de que havia diversos militares cruéis e ávidos por poder e uma esquerda que resolveu guerrear contra os militares sanguinários. Para Calveiro, não será possível explicar toda uma organização social ou um conflito por via binária, isto é, de forma polarizada em que dois grupos se enfrentam mutuamente, sendo assim, afirma Calveiro:

La lucha, la confrontación y la revolución como formas, si no únicas, válidas y valiosas de la política. Se definían y guardaban las fronteras nacionales, ideológicas, de gênero -. Existia una extraordinaria tendencia a realizar clasificaciones y, sobre todo, formas de organización binarias explorados y exploradores, justo e injusto, correcto e interrecto (CALVEIRO, 2013: 14).

Com os trabalhos revisionistas recentes sobre a guerrilha revolucionária na Argentina têm surgido diversas interpretações e entendimentos sobre o papel político desempenhado pela esquerda armada naquele país. Apesar de esses trabalhos reconhecerem o genocídio cometido por militares em 1976, contra os opositores, eles tendem a não isentar a responsabilidade da guerrilha revolucionária no cometimento da violência.

De acordo com essas interpretações, a violência política teria emergido na Argentina com a guerrilha. Isso porque a guerrilha não teria compreendido os valores da democracia. Dessa forma, a guerrilha com sua ação violenta teria provocado o golpe. De modo, quando pesquisamos o passado histórico percebemos as diferentes formas de elaboração do revisionismo.

No Brasil e na Argentina tanto a direita quanto a esquerda utilizaram o revisionismo como justificativa ideológica para suas ações no passado, ou seja, foi uma forma encontrada para dar sentido epistemológico as suas ações políticas e identitárias no passado histórico.

No entanto, quando estudamos processos históricos que foram traumáticos para a sociedade nos devemos questionar quais foram os parâmetros éticos dessas ações tanto da esquerda armada quanto dos regimes ditatoriais. 


\section{Considerações Finais}

Assim, como em outros episódios traumáticos para a humanidade como a Segunda Guerra Mundial e o genocídio de judeus causado pelo Holocausto, a violência tem sido parâmetro para estudar os golpes militares no Continente Latino-Americano. Salvo as peculiaridades entre a ditadura argentina (1976-1983) e a brasileira (19641985), a violência tem sido a chave para compreender a vitória dos regimes militares sob os grupos de esquerda que empunharam armas contra esses regimes.

Nesse sentido, abrem-se parênteses para que possamos compreender como essas peculiaridades podem contribuir para a compreensão desses conflitos tanto na Argentina quanto no Brasil.

Com base nas leituras podemos concluir que apesar da ditadura militar na Argentina ter sido mais breve, ela também teve desempenho mais violento. Todavia, isso não significa afirmar que a ditadura no Brasil não cometeu violência. Aqui, também a ditadura violou gravemente os direitos humanos, centenas pessoas foram presas, torturadas e assassinadas.

Mas quando analisamos esses dois episódios traumáticos pelo viés da memória social que foi construída percebemos outra diferença. Lá existe toda uma análise sobre o uso da violência tanto pelo Estado quanto pela esquerda revolucionária. A teoria dos dois demônios é um exemplo para se pensar como o radicalismo político de ambos foi capaz de vitimar a sociedade.

Já no Brasil os trabalhos de memória de ex-militantes tocam na temática da violência, mas ressaltam o sentimento de frustração da guerrilha armada. Frustração essa que vai desde a falta de preparo militar, passando pelas cisões internas da esquerda brasileira e chegando a falta de adesão popular. 


\section{Referências Bibliográficas}

ALVES, Maria Helena Moreira (1984). Estado e oposição no Brasil (1964-1984). Petrópolis: Vozes.

CALVEIRO, Pilar (2013). Política y / o violencia: una aproximación a la guerrilla de los años setenta. $1^{a}$ ed. Buenos Aires: Siglo Veintiuno Editores.

CERTEAU, Michel de (2014). A invenção do cotidiano: 1 . Artes de fazer. Petrópolis: Vozes.

FAUSTO, Boris (2012). História Concisa do Brasil. 2. ed. São Paulo: USP.

FICO, Carlos (2001). Como eles agiam. Rio de janeiro: Record.

FILHO, Daniel Aarão Reis (1990). A revolução faltou ao encontro: os comunistas no Brasil. São Paulo: Brasiliense.

FRANCO, Marina (2005). Reflexiones sobre la historiografía argentina y la historia reciente de los años '70. Nuevo Topo. Revista de historia y pensamiento crítico. Buenos Aires, n. 1, set./out. 2005. Disponível em: $<$ https://issuu.com/nuevotopo/docs/franco_nt1?documentId=090218201324ff0f0ec7564c41ba9536e5e2847a9a98\&layout=white\&e=1130499/2718688>. Acesso em: 26 jul. 2016.

GORENDER, Jacob (1987). Combate nas trevas - a esquerda brasileira: das ilusões perdidas à luta armada. São Paulo: Ática.

JORNAL Em Tempo comemora 30 anos. (2008). Disponível em: $<$ http://cartamaior.com.br/?/Editoria/Politica/Jornal-Em-Tempo-comemora-30anos-/4/14099\#>. Acesso em: 20 de jul. 2016.

LE GOFF, Jacques (2013). História e memória. 7. Ed. Campinas, SP: Unicamp.

LORIGA, Sabiana (2009). A tarefa do historiador. In: GOMES, Angela de Castro; SCHMIDT, Benito Bisso. (Org.). Memória e narrativas (auto)biográficas. Rio de Janeiro: FGV.

NAPOLITANO, Marcos (2015). Recordar é Vencer: as dinâmicas e vicissitudes da construção da memória sobre o regime militar brasileiro. Londrina. Revista Antíteses, v. 8, p. 09-44, nov. Disponível em: < http://www.uel.br/revistas/uel/index.php/antiteses/article/view/23617>. Acesso em: 20 jul. 2016.

QUADRAT, Samantha Viz (2011). Ditadura, violência política e direitos humanos na Argentina, no Brasil e no Chile. In: AZEVEDO, Cecília; RAMINELLI, Ronald. História das Américas: novas perspectivas. Rio de Janeiro: Editora FGV, pp. 240273.

REIS, Daniel Aarão (2004). Ditadura e sociedade: as reconstruções da memória. In: REIS, Daniel Aarão; RIDENTI, Marcelo; MOTTA, Rodrigo Patto Sá (Orgs.). $O$ golpe e a ditadura militar 40 anos depois (1964-2004). Bauru, SP: Editora da Universidade do Sagrado Coração (EDUSC), pp. 29-52.

REZENDE, Maria José de (2001). A ditadura militar no Brasil: repressão e pretensão de legitimidade 1964-1985. Londrina: Ed. UEL.

RIDENTI, Marcelo (2007). Esquerdas revolucionárias armadas nos anos 1960-1970. In: FERREIRA, Jorge; REIS, Daniel Aarão. Revolução e democracia (1964...). Rio de Janeiro: Civilização Brasileira. (As esquerda no Brasil; v.3), pp. 21- 51. (1993). O fantasma da revolução brasileira. São Paulo: Unesp.

ROLLEMBERG, Denise (2006). Esquecimento das memórias. In: FILHO, João Roberto Martins (Org.). O golpe de 1964 e o regime militar: novas perspectivas. São Carlos: EdUFSCar, pp. 81-91. 
SALES, Jean Rodrigues (2015). Guerrilha e revolução: um balanço dos estudos e debates sobre a luta armada contra a ditadura militar no Brasil. Revista Taller, v. 4, pp. 87-109.

VEZZETTI, Hugo (2007). Conflictos de la memoria en la Argentina. Un estudio histórico de la memoria social. Disponível em: <http://www.historizarelpasadovivo.cl/downloads/vezzetti.pdf>. Acesso em: 23 de jul. de 2016.

Artigo recebido em 15 de abril de 2017.

Aprovado em 27 de julho de 2017.

DOI: $10.12957 /$ intellectus.2017.28339 